\author{
Article \\ Doi 10.5943/mycosphere/8/9/4 \\ Copyright $(\mathcal{C}$ Guizhou Academy of Agricultural Sciences
}

\title{
Yeasts and filamentous fungi inhabiting guts of three insect species in Assiut, Egypt
}

\author{
Moubasher AH ${ }^{1,2, *}$, Abdel-Sater MA ${ }^{1,2}$ and Zeinab Soliman ${ }^{2}$ \\ ${ }^{1}$ Department of Botany and Microbiology, Faculty of Science, Assiut University, P.O. Box 71526, Egypt \\ ${ }^{2}$ Assiut University Mycological Centre, Assiut University, P.O. Box 71526, Egypt \\ *Corressponding author: e-mail: ahamaumc@yahoo.com, Phone \& Fax: (+20) 088 2080153, mobile: (+20) \\ 01223598670
}

Moubasher AH, Abdel-Sater MA, Zeinab Soliman 2017 -Yeasts and filamentous fungi inhabiting guts of three insect species in Assiut, Egypt. Mycosphere 8(9), 1297-1316, Doi 10.5943/mycosphere/8/9/4

\begin{abstract}
This work aimed to evaluate for the first time in Egypt the biodiversity of mycobiota that inhabit the guts of three insect species collected from Assiut Governorate. 50 adult insect samples ( 28 worker honey bees, 11 black beetles and 11 red palm weevils) were analyzed. 68 species and three varieties were recovered of which 49 species and 2 varieties were filamentous fungi and 19 species + one variety were yeasts. The number of taxa recovered from red-palm weevils and honey bees was almost equal, while lower number was isolated from beetles. However, a higher number of yeast species was obtained from the gut of red-palm weevils than those obtained from honey bees or black beetles. Some filamentous species were recovered from the guts of the three insect species (Aspergillus niger, A. parasiticus, A. terreus, Cladosporium cladosporioides, Penicillium chrysogenum), while others were reported from one or two insect species. However, none of yeast species was regularly recovered from the three insect guts, but two insect species may share the same yeast species in their guts. Other yeast species were restrictedly isolated from guts of one insect species. Some gut samples were fungi-free. To our knowledge, some of the isolated yeast species are being reported here for the first time from insect guts. On the other hand, ITS sequence data from several strains did not match well with those of known described species, and are probably new species.
\end{abstract}

Keywords - Beetles - honey bees - phenotypic and genotypic characteristics - red-palm weevils

\section{Introduction}

Yeasts have been isolated frequently from the gut or surface of insects that feed on a variety of materials, including basidiomycete fruiting bodies, woody substrates, ephemeral flowers and nectar exudates (Kurtzman 2001, Lachance et al. 2001a, b, 2005, Rosa et al. 2003, Suh et al. 2003, 2004b, 2005a, b, Teixeira et al. 2003; Suh \& Blackwell 2004, 2005, Pimentel et al. 2005, Nguyen et al. 2006). Yeasts have been also described as endosymbionts in mosquito populations, lacewings, beetles and homoptera (Ganter 2006, Urubschurov \& Janczyk 2011). Gut-inhabiting fungi are known 
to be essential for the nutrition of many insects (Nardon \& Grenier 1989, Vega \& Dowd 2005), the insects also rely on yeasts for various metabolic functions, including synthesis of amino acids, vitamins, lipids, sterols and pheromones, degradation of nutritional substrates, and detoxification of compounds (Suh et al. 2003, Vega \& Dowd 2005, Starmer \& Lachance 2011). Yeast isolations from the gut of insects have led to discovery of a large number of new species of yeasts (Suh et al. 2003, 2004a, b, 2005b, 2006, Suh \& Blackwell 2004, 2006, Berkov et al. 2007, Rivera et al. 2009, Grunwald et al. 2010, Houseknecht et al. 2011, Calderon \& Berkov 2012). Despite these efforts, the diversity of gut-inhabiting yeasts remains understudied.

On the other hand, many species of filamentous fungi have been isolated from the guts of several insect species (Gilliam et al. 1974a, Rios-Velasquez \& Hamada 2002, Gilliam 1997, Moraes et al. 2000, 2004, Marti et al. 2007, Vale et al. 2008, Wang et al. 2010, Chahbar \& Mohamed 2014, Rojas-Jimenez \& Hernandez 2015). The isolation of these fungi from insect guts suggests that these insects rely on these fungal species to assimilate the complex polysaccharides (cellulose and hemicelluloses) and phenylpropane polymers (lignin) (Rojas-Jimenez \& Hernandez 2015) that comprise the secondary cell walls of woody plants and constitute the basic nutrition source for a large number of insects (Perez et al. 2002, Berenbaum \& Eisner 2008).

Molecular techniques used since 2000 have greatly enhanced the number of new species identified. Molecular techniques, combined with microbiological and physiological tests, are being used to characterize yeast isolates and species. Most of the analyses have used rDNA sequences, however, we now know that there are no universal criteria to distinguish between genera (Barriaga et al. 2011).

The aim of this work was to identify and evaluate the biodiversity of yeasts and filamentous fungi that might inhabit the guts of three insect species collected from Assiut Governorate, Egypt. The identification was based on phenotypic characteristics in case of filamentous fungi and physiological and genotypic characteristics in case of yeasts.

\section{Materials \& Methods}

\section{Collection of insects}

A total of 50 adult insect samples of three different species were collected, 28 samples from honey bees (Apis mellifera L., order: Hymenoptera, family: Apidae), eleven samples from black beetles (Pterostichus melanarius Illiger, order: Coleoptera, family: Carabidae), and eleven samples from red palm weevils, RPW (Rhynchophorus ferrugineus Olivier, order: Coleoptera, family: Curculionidae). Workers of honey bees from beehives (in June 2014) and red-palm weevils (in July 2013, February and March 2014) were kindly supplied by the Faculty of Agriculture, Assiut University, while black beetles were collected in July 2013, May and June 2014 from some farms in Assiut Governorate, Egypt. Insects obtained were put in separate clean containers (bottles or plastic bags) and kept for 3 days with slightly moistened filter paper so that surface debris is removed.

\section{Dissection of insects to obtain guts}

Insect samples were put each in a $250 \mathrm{ml}$ conical flask with $95 \%$ ethyl alcohol for 1-2 minutes and were then washed several times with sterile distilled water for surface sterilization. They were dissected using forceps (or pins) in a sterile Petri dish, and the gut was removed aseptically from body.

\section{Isolation of yeasts and filamentous fungi from insect guts}

The gut is transferred into a sterile $1.5 \mathrm{ml}$ Eppendorf tube containing $200 \mu \mathrm{l}$ of $0.7 \%$ sterile saline solution. The gut is crushed with a pipette tip, and all the solution (including gut pieces) was spread with a loop over the surface of YM agar and acidified YM agar plates (at least three replicateplates for each medium type and each gut sample). The inoculated plates were incubated at $25^{\circ} \mathrm{C}$ for 3-7 days (Suh \& Blackwell 2004). The gut plates were checked every day and the developing colonies were observed under a microscope to check yeasts and filamentous fungi. A water mount of a piece 
of the colony was made and observed under a microscope if necessary. Bacterial colonies often developing on YM (distinguishable from yeasts by their cell sizes) were not considered. A single colony was picked up, and streaked three times by crossing the lines onto a fresh acidified YM (single colony isolation).

\section{Media used for isolation of fungi}

Two media were used: Yeast extract-malt extract-peptone-glucose agar, YM (Wickerham $1951)$ of the following composition was employed: $(\mathrm{g} / \mathrm{l})$ yeast extract 3.0, malt extract 3.0, peptone 5.0, glucose 10.0, agar 20.0. Chloramphenicol $(250 \mu \mathrm{g} / \mathrm{ml})$ was used as a bacteriostatic agent. The medium is dispensed into containers and autoclaved at $121^{\circ} \mathrm{C}$ for 15 minutes. The other medium was acidified yeast extract-malt extract-peptone-glucose agar, AYM (Wickerham 1951) of the same composition as YM but acidified by a predetermined volume of $1 \mathrm{~N}$ hydrochloric acid (approximately $0.7 \%, \mathrm{v} / \mathrm{v}$ ) to give the desired $\mathrm{pH}$ of 3.7 to 3.8 .

\section{Phenotypic identification of the insect-associated filamentous fungi}

The fungi were identified based on their macro- and microscopical features following the keys of Raper \& Fennell (1965), Pitt (1979), Sivanesan (1987), Moubasher (1993), Zare \& Gams (2004), Leslie \& Summerell (2006) and Domsch et al. (2007).

\section{Physiological characterization of yeast strains}

Fermentation of sugars and oxidative utilization of carbon compounds were performed according to Barnett et al. (2000). Assimilation of nine nitrogen compounds (potassium nitrate, sodium nitrite, ethylamine, L-lysine, creatine, creatinine, D-glucosamine, imidazole, or Dtryptophan) was determined (Suh et al. 2008b). Growth at high osmotic pressure, in the presence of cycloheximide and production of extracellular starch-like compounds were also tested (Suh et al. 2008b). Identification keys of Barnett et al. (2000) were followed to assign each isolate to its species level. Confirmations of these identifications were carried out using the molecular technique.

\section{Genotypic identification of yeast strains}

The yeast strains were grown on YM plates and incubated at $25^{\circ} \mathrm{C}$ for 2 days. A small amount of yeast growth was scraped off and suspended in $100 \mu \mathrm{l}$ of distilled water and boiled at $100{ }^{\circ} \mathrm{C}$ for 15 minutes following the manufacturer's protocol (SolGent Company, Daejeon, South Korea). The samples were directly sent for extraction and sequencing or they were collected in a batch and stored at $-70{ }^{\circ} \mathrm{C}$ before sending to Korea. Yeast DNA was extracted and isolated using SolGent purification beads at this company. Internal transcribed spacer (ITS) sequences of nuclear ribosomal DNA were amplified using the universal primer ITS1 (5'- TCC GTA GGT GAA CCT GCG G -3'), and ITS4 (5'TCC TCC GCT TAT TGA TAT GC -3'). Then amplification was performed using the polymerase chain reaction (PCR) (The GeneAmp® PCR System 9700 thermal cycler, Applied Biosystems, Foster City, California, USA). The PCR reaction mixtures were prepared using SolGent EF-Taq as follows: 10X EF-Taq buffer $2.5 \mu \mathrm{l}, 10 \mathrm{mMdNTP}(\mathrm{T}) 0.5 \mu \mathrm{l}$, primer (F-10p) $1.0 \mu \mathrm{l}$, primer (R-10p) $1.0 \mu \mathrm{l}$, EF-Taq ( $2.5 \mathrm{U}$ ) $0.25 \mu \mathrm{l}$, template $1.0 \mu \mathrm{l}$, DW up to $25 \mu \mathrm{l}$. Then the amplification was carried out using the following PCR reaction conditions: one round of amplification consisting of denaturation at $95{ }^{\circ} \mathrm{C}$ for 15 minutes followed by 30 cycles of denaturation at $95{ }^{\circ} \mathrm{C}$ for 20 seconds, annealing at $50{ }^{\circ} \mathrm{C}$ for 40 seconds and extension at $72{ }^{\circ} \mathrm{C}$ for 1 minute, with a final extension step of $72{ }^{\circ} \mathrm{C}$ for 5 minutes.

The PCR products were then purified with the SolGent PCR Purification Kit-Ultra (SolGent, Daejeon, South Korea) prior to sequencing. After that, the purified PCR products were reconfirmed (using size marker) by electrophoreses of the PCR products on $1 \%$ agarose gel. These bands were then eluted and sequenced. Each sample was sequenced in sense and antisense direction.

Contigs were created from the sequence data using the CLCBio Main Workbench program. The sequence obtained from each isolate was further analysed using BLAST from the National Center of Biotechnology Information (NCBI) website. Sequences obtained together with those 
retrieved from the GenBank database were subjected to the Clustal W analysis using MegAlign software version 5.05 (DNASTAR Inc., Madison, Wisconsin, USA) for the phylogenetic analysis (Thompson et al. 1994).

\section{Results}

\section{Total fungi recovered from guts of the three insect species investigated}

The yeast isolates were characterized using phenotypic, physiological and molecular methods (Tables 1,2), while filamentous fungi were identified using only phenotypic characteristics based on their macro- and microscopic features. Representative strains of the species recovered are deposited at Assiut University Mycological Center Culture Collection (AUMC) and ITS gene sequences of the yeast strains were deposited at National Center for Biotechnological Information (NCBI) and accession numbers are given for them (Table 2).

A total of 67 species and three varieties belonging to 34 genera were recovered on yeast extract malt extract agar (YM) and acidified yeast extract malt extract agar (AYM) from 50 gut samples of the three different insect species. From these, 48 species and two varieties assigned to 21 genera were filamentous fungi and 19 species + one variety belong to 15 genera were yeasts. The number of taxa recovered from honey bees ( 37 species and one variety belonged to 21 genera) and red-palm weevils (35 species and one variety related to 21 genera) was almost equal, while lower number was isolated from black beetles ( 20 species + one variety assigned to nine genera). However, higher number of yeast species $(14+$ one variety) was obtained from the gut of red-palm weevils than those obtained from honey bees (6 species) or black beetles (five species) (Table 3 ).

\section{Fungi recovered from guts of honey bees}

In the present investigation, thirty-eight species and one variety belonging to 21 genera were isolated from 28 gut samples of honey bees. Filamentous fungi were recovered from 21 samples and represented by 31 species, one variety and 16 genera while yeast fungi were isolated from 16 samples and represented by six species related to five genera.

Aspergillus (11 species) was isolated in high frequency from bee samples (18 out of 28 samples analyzed). Aspergillus niger was the most common species recovered from 12 samples, followed by A. flavus ( 7 samples) and A. terreus ( 5 samples). The remaining aspergilli were isolated from one or two samples only (Table 3 ).

Both Cladosporium (4 species) and Penicillium (2 species) were recovered in low frequency (6 samples each) and C. cladosporioides, $C$. herbarum, $P$. chrysogenum and P. oxalicum were the most common species. Chaetomium sp. was isolated from five samples, whereas Scopulariopsis brevicaulis was isolated from three samples. On the other hand, Cochliobolus (3 species) and Mucor hiemalis were recovered each from two samples, and Bipolaris clavata, Fusarium verticillioides, Myceliophthora thermophila, Nigrospora oryzae, Papulaspora immerse, Pochonia suchlasporia var. catenata and Trichothecium roseum were encountered each from one sample only.

From yeasts Lachancea thermotolerans was the most common in the gut of honey bees; it was isolated from ten samples. Pichia (represented by $P$. kudriazevii) and Saccharomyces (represented by S. cerevisiae and Saccharomyces sp. near to S. cerevisiae, less than 95\% ITS sequence identities with the type strain) were recovered in seven samples each. Wickerhamomyces subpelliculosus was isolated from 4 gut samples while Hanseniaspora opuntiae was recovered from one sample only.

\section{Fungi recovered from guts of black beetles}

Twenty species and one variety belonging to nine genera were isolated from eleven gut samples of black beetles. Filamentous fungi were recovered from all samples and represented by 15 species and one variety belonging to five genera, while yeast fungi represented by five species related to four genera were isolated from four gut samples. 
Aspergillus ( 7 species and 1 variety) was recovered in ten samples out of eleven investigated. A. niger was also the most common species and was encountered in eight samples, followed by $A$. terreus (in 3 samples), and A. parasiticus and A. taichungensis (in 2 samples), while the remaining aspergilli were isolated each from one gut sample only (Table 3 ).

Cladosporium and Penicillium (3 species each) were recovered from six and five samples, respectively with $C$. sphaerospermum and $P$. chrysogenum being the most common. Scopulariopsis chartarum was isolated from two samples and Chaetomium sp. from one sample only.

From yeasts, Candida fermentati was isolated in two samples while $C$. parapsilosis, $C$. tropicalis, Exobasidium sp., and Cyberindnera jadinii were encountered each from one sample only.

\section{Fungi recovered from guts of red-palm weevils}

Thirty-five species and one variety belonging to 21 genera were recovered from eleven gut samples of red-palm weevils. Filamentous fungi were recovered from nine samples and represented by 21 species assigned to ten genera, while yeast fungi were isolated from all samples and represented by 14 species and one variety related to eleven genera (Table 3 ).

Cladosporium ( 3 species) and Fusarium ( 2 species) were isolated in moderate frequency (5 samples each). $C$. cladosporioides and $F$. solani were the most common species.

Aspergillus (6 species) was recovered from four samples. A. niger and A.terreus were isolated each from two samples. The remaining four aspergilli were isolated each from one sample only (Table 3).

Gondwanamyces (G. serotectus) and Penicillium (4 species) were recovered each from only two samples, while Cunninghamella echinulata, Mucor circinelloides, Pseudallescheria boydii, Scopulariopsis japonicum, Stemphylium sarciniforme and Triadelphia near to T. disseminata were encountered each from one gut sample.

Cyberlindnera jadinii was the most common yeast fungus isolated from all gut samples of red-palm weevil investigated, followed by Prototheca zopfii var. hydrocarbonea was also recovered in high frequency ( 9 samples). Candida (5 species) was also isolated in high frequency ( 7 samples) with $C$. tropicalis being the most common Candida species; it was isolated from four samples. $C$. aaseri, C. pararugosa, and C. quercitrusa were recovered each from 2 samples while $C$. parapsilosis was encountered from one sample only. Saccharomyces cerevisiae was isolated in moderate frequency (5 samples). Reniforma sp. near to R. strues (87\% similarity with the type strain, Table 2, probably a new species) and Meyerozyma carribbica were isolated each from two samples while Cryptococccus magnus, Debaryomyces nepalensis, Exobasidium sp., Saccharomycopsis fibuligera and Sterigmatomyces elviae were encountered each from 1 sample only.

\section{Overview on the gut mycobiota of the three insect species}

The number of fungal taxa recovered from red-palm weevils and honey bees was almost equal, while lower number was isolated from black beetles. However, higher number of yeast species $(14+1$ variety) was obtained from the gut of red-palm weevils than those obtained from honey bees (6 species) or black beetles ( 5 species). Yeasts and filamentous fungi were isolated more frequently in guts of red palm weevil (100\% and $81.81 \%$ of the samples respectively) than in honey bees $(57.14 \%$ and $75 \%)$ and black beetles $(36.36 \%$ and $100 \%)$. Some filamentous species were recovered from guts of the 3 insect species (Aspergillus niger, A. parasiticus, A. terreus, Cladosporium cladosporioides, Penicillium chrysogenum), while others were reported from guts of one or two insect species. However, none of yeast species was regularly recovered from the three insect guts, but two insects may share the same yeast species in their guts (Candida parapsilosis, C. tropicalis, Cyberlindnera jadinii, Exobasidium sp., Meyerozyma carribbica from both black beetles and red palm weevils; and Saccharomyces cerevisiae from both honey bees and red palm weevils). Other species were restrictedly isolated from guts of one insect species. To our knowledge, some of the isolated fungal species are reported here for the first time from guts of either adults of red palm weevil (Gondwanamyces serotectus, Triadelphia sp. near to T. disseminata, Candida aaseri, C. pararugosa, C. quercitrusa, Cryptococcus magnus, Cyberlindnera jadinii, Debaryomyces nepalensis, 
Exobasidium sp., Reniforma sp. near to S. strues, Saccharomycopsis fibuligera and Sterigmatomyces elviae and Prottheca zopfii var. hydrocarbonea), from worker honey bees (Hanseniaspora opuntia and Wickerhamomyces subpelliculosus) or from black beetle gut (Exobasidium sp.) and are being considered in another publication. On the other hand, some strains are far from the known described species (based on their low ITS sequence similarities < $95 \%$ with those deposited in the Genbank) and probably some of these could be new species such as KX023220-KX023223, KX029122, KX029124, KX029125, KX015906, KX015907, KX015909-KX015911, KX029126, KX011609 and KX015891 (listed in Table 2). More studies on these strains are in progress.

\section{Discussion}

\section{Total fungi recovered from guts of the three insect species}

Phenotypic, physiological and molecular methods were used to characterize yeast isolates, while macro- and microscopic features were used for identification of filamentous fungi. Strains of the species recovered were deposited at Assiut University Mycological Center AUMC and ITS gene sequences of the yeast strains were deposited at NCBI. 68 species and three varieties belonging to 36 genera were recovered from gut samples of the three insect species investigated. The number of taxa recovered from honey bees and red-palm weevils was almost equal, while lower number was isolated from black beetles. However, higher number of yeast species was obtained from the gut of red-palm weevils than those obtained from honey bees or black beetles. The gut of insects of several families is found as a productive environment and is rich in yeasts that carry out the fermentation of cellobiose and xylose (Suh et al. 2003, Urbina et al. 2013). Urbina et al. (2013) reported the isolation of ascomyceteous and basidiomyceteous yeasts from the gut of the 16 species of passalid beetles collected in nine localities in Guatemala with the xylose-fermenting (X-F) yeasts were the most abundant taxa isolated. Also beetle guts (Callaham \& Shifrine 1960, Suh et al. 2003, 2004a, 2005a,b, 2008a, Suh \& Blackwell 2004, Houseknecht et al. 2011), honey bee guts (Gilliam et al. 1974a, b, Sandhu \& Waraich 1985, Chahbar \& Mohamed 2014) and guts from other insect species (Nguyen et al. 2007, Urubschurov \& Janczyk 2011, Hui et al. 2012, 2013, Bagde et al. 2013, Urbina et al. 2013, Rojas-Jimenez \& Hernanddez 2015) were reported as a good source of hyper-diverse source of yeasts and filamentous fungi.

\section{Fungi recovered from guts of honey bees}

As the health of honey bees and the quality of honey is affected by many microbes, thus there is the need of isolating and identifying these microbes so as to find out the means of controlling them. Insect gut microbiota plays essential role in the growth, development, pathogenesis and environmental adaptation of host insects (Bhat et al. 2014). Composition of the digestive microbiota of honey bees is the result of feeding pollen and nectar, but also it is a consequence of interaction among the bees in the hive (Glinski \& Jarosz 1995).

In the current work, 38 species and one variety were isolated from 28 gut samples of honey bees. 32 filamentous fungal species were recovered from 21 samples while only 6 yeast species were recorded from 16 samples only. In this respect, 18 species of filamentous fungi (Gilliam et al. 1974a) and seven of yeasts (Gilliam et al. 1974b) were previously isolated from the intestinal tracts of 388 adult worker honey bees. Moreover, Gilliam (1997) stated that not all bees contained yeasts, and the numbers of yeasts varied from colony to colony.

Nine species of Aspergillus were reported, with A. niger (from 12 samples), A. flavus ( 7 samples) and A. terreus (5 samples) being the most common, followed by Cladosporium cladosporioides, C. herbarum, Penicillium chrysogenum, P. oxalicum and Chaetomium sp. On the other hand, species of Scopulariopsis (1 species), Cochliobolus (3) and Mucor (1) were recovered each from two or three samples, while other species were encountered each from one sample only. In harmony with the current results, filamentous fungi previously reported from the intestinal tract of worker honey bees include species of Penicillium, Aspergillus, Cladosporium, Alternaria, Bipolaris, Curvularia and Rhizopus of which Penicillium frequentans, P. cyclopium, Aspergillus 
flavus, A. niger, Alternaria tenuissima and Cladosporium cladosporioides were found most frequently (Gilliam \& Prest 1972, Gilliam et al. 1974a, 1977, 1988a). However no filamentous fungi were recovered from the digestive tracts of 2 Algerian subspecies worker honeybees (Apis mellifera intermissa and A. mellifera sahariensis) during the two seasons (winter and spring) of the year 2012, but strains of these obtained from bee bread were identified to the generic level as Penicillium, Aspergillus, Cladosporium, Alternaria and Mucor (Chahbar \& Mohamed 2014). From yeasts Lachancea thermotolerans was the most common yeast fungus in the gut of honey bees followed by Pichia kudriazevii, two Saccharomyces spp. and Wickerhamomyces subpelliculosus while Hanseniaspora opuntiae was recovered from one sample only. L. thermotolerans was recently isolated from the gut of honey bee (Mousavi et al. 2015). In the work of Gilliam et al. (1974b, 1977), guts of adult worker honey bees emerged different spectrum of yeast species in the following order of frequency: Torulopsis magnoliae, T. glabrata, Candida parapsilosis, Hansenula anomala, Saccharomyces bailii var. osmophilus, Rhodotorula minuta var. minuta and Cryptococcus albidus var. aerius. Also it was stated that intestinal yeasts were most frequently encountered in worker bees that live under stress conditions (Gilliam 1973, Gilliam et al. 1974b, 1977, 1979, 1988b) and intestinal yeasts were isolated from 21 bees from free-flying colonies in the fall (Gilliam et al. 1988a). Sandhu \& Waraich (1985) obtained 473 yeast isolates from 328 stomach samples of seven different pollinating bee species (including A. mellifera) that were identified to 13 genera and 30 species, of these Dekkera intermedia and Saccharomyces cerevisiae followed by Candida humicola, $C$. incommunis, C. ishiwadae, C. membranaefaciens, C. parapsilosis, Rhodotorula lactosa and Cryptococcus albidus were the most common. However, Chahbar \& Mohamed (2014) found no yeasts in the digestive tracts of two Algerian subspecies worker honeybees, but yeast strains were obtained from bee bread and are likely to belong to the genus Saccharomyces.

\section{Fungi recovered from guts of black beetles}

All gut samples of black beetles yielded 15 species and one variety of filamentous fungi however, four gut samples only yielded five yeast species. Suh et al. (2005a) stated that beetle gut is a hyperdiverse source of novel species since they isolated over 650 yeast strains over a three year period from the gut of beetles from 27 taxa and found that at least 200 of these were undescribed taxa. Some of the yeasts recovered were basidiomycetes, but the vast majority was ascomycete budding yeasts (Saccharomycetes).

Aspergillus niger was also the most commonly encountered species (from 8 samples) followed by $P$. chrysogenum (5), A. terreus, C. sphaerospermum (3) and A. parasiticus, A. taichungensis and Scopulariopsis chartarum (2 samples each) from black beetle guts, while other species were encountered each from only one gut sample. In their study on fungi associated with the guts of tropical wood-feeding beetle larvae of Coleoptera, Rojas-Jimenez \& Hernandez (2015) obtained 92 strains of filamentous and yeast fungi and assigned them to 40 genera mostly related to Ascomycota (32 genera), then Basidiomycota (6) and Zygomycota (2) with Trichoderma being the most abundant fungus, and Penicillium, Paecilomyces, Fusarium, Aspergillus and Mucor were among the isolated fungi. In the studies of Moraes et al. (2000, 2004), 758 fungal strains were recovered from the digestive tract of many individuals of adult insects and nymphs of nine species triatomine bugs (Order: Hemiptera); they found that the genera with the greatest number of species were Penicillium, Aspergillus, Acremonium, Cladosporium and Paecilomyces and the most frequent species in both studies were $P$. corylophilum, P. fellutanum, P. waksmanii, Aspergillus niger, A. awamori, Cladosporium herbarum and Paecilomyces variotii. The digestive tract of Triatoma infestans (Hemiptera) yielded also 33 species of fungi of which Penicillium (15 species), Aspergillus (5) and Cladosporium (2) gave rise the greatest number of species (Marti et al. 2007). Candida fermentati was isolated in 2 gut samples of black beetles while $C$. parapsilosis and C. tropicalis, Exobasidium sp. and Cyberindnera jadinii were encountered each from 1 sample only.

C. fermentati and other three new Candida species (Suh and Blackwell 2004), Candida ambrosiae and 16 new Candida species (Suh et al. 2004b) were isolated from the digestive tract of 
basidiocarp-feeding beetles. Species of Sugiyamaella and Candida (including a new Candida species) were isolated from the gut of wood-ingesting beetles (Houseknecht et al. 2011).

In their study on fungi associated with the guts of tropical wood-feeding beetle larvae of Coleoptera, Rojas-Jimenez \& Hernandez (2015) obtained two strains of Trichosporon and two strains of Geotrichum. Pichia stipitatis-like yeasts were consistently isolated from the gut of wood-ingesting passalid beetles (Suh et al. 2003). Isolates from the digestive tracts of plant-associated beetles and other insects were identified as Candida orthopsilosis, C. maltosa, C. pseudorhagii, C. parapsilosis, C. tropicalis, $C$. neerlandica, Lodderomyces elongisporus and seven new Candida species near to $C$. albicans (Suh et al. 2008a); also nine new Candida species near C. membranifaciens were isolated from the gut of a variety of insects (including beetles, lacewings, fishflies, craneflies and a cockroach) (Suh et al. 2005b). Novel species of Candida (Kurtzman \& Robnett 1998, Hui et al. 2012) and Wickerhamomyces (Hui et al. 2013) were described from guts or frass of wood-boring insect larvae or ambrosia beetle.

\section{Fungi recovered from guts of red-palm weevils}

The red palm weevil (RPW) is widely considered the most damaging insect pest of palms in the world, even in all the countries where it has been accidentally introduced (Cox, 1993). Since the 1980s it has rapidly expanded its geographical range westwards. It reached Saudi Arabia and the United Arab Emirates in about 1985, spreading throughout the Middle East and it had been introduced to Egypt in 1992 (Cox 1993), with thousands of healthy trees being damaged or lost (ElSebaey 2004). RPW larvae feed within the apical growing point of the palms, producing a wet fermenting frass inside the tunnels (Butera et al. 2012) creating extensive damage to palm tissues and weakening the structure of the palm trunk; the resulting damage is often only visible long after infestation, when palms are close to death (Ferry \& Gomez 2002, Faleiro 2006, Dembilio \& Jacas 2011).

\section{Acknowledgements}

The authors are indebted to the Assiut University Mycological Centre, Assiut University, Egypt for financial support of this work. The authors also declare that there is no conflict of interest. The authors alone are responsible for the content and the writing of the paper.

\section{References}

Bagde US, Gopi U, Prasad R. 2013 - Isolation and characterization of gut-associated microbes in cockroach. African Journal of Microbiology Research 7, 2034-2039.

Barnett JA, Payne RW, Yarrow D. 2000 - Yeasts: characteristics and identification. $3^{\text {rd }}$ ed., Cambridge University Press, London, UK.

Barriaga EJC, Libkind D, Briones AI, Iranzo JÚ, Portero P, Roberts I, James S, Morais PB, Rosa CA. 2011 - Yeasts biodiversity and its significance: Case studies in natural and human-related environments, ex situ preservation, applications and challenges: In Grillo O, Venora G (eds), Changing diversity in changing environment, Published by InTech, Janeza Trdine 9, 51000 Rijeka, Croatia, pp. 55-86.

Berenbaum MR, Eisner T. 2008 - Ecology: Bugs' bugs. Science 322, 52-53.

Berkov A, Feinstein J, Small J, Nkamany M. 2007 - Yeasts isolated from neotropical wood-boring beetles in SE Peru. Biotropica 39, 530-538.

Bhat SA, Nazir R, Ahmad SF, Bhat GA. 2014 - Exploiting gut microbial diversity of honey bees of temperate climate of Kashmir valley. Natural Science 12, 105-110.

Butera G, Ferraro C, Colazza S, Alonzo G, Quatrini P. 2012 - The culturable bacterial community of frass produced by larvae of Rhynchophorus ferrugineus Olivier (Coleoptera: Curculionidae) in the Canary island date palm. Letters in Applied Microbiology 54, 530-536. 
Table 1 Physiological comparison of the strains tested of the recorded yeast species.

Ascomyceteous species: 1 Candida aaseri AUMC 10247, 2 C. fermentati (Saito) Bai (teleomorph: Meyerozyma caribbica) AUMC 10242, 3 C. krusei (Castellani) Berkhout (teleomorph: Pichia kudriavzevii) AUMC 10226, 4 C. parapsilosis AUMC 10243, 5 C. pararugosa AUMC 10248, 6 C. quercitrusa AUMC 10249, 7 C. tropicalis AUMC 10245, 8 Cyberlindera jadinii AUMC 10246, 9 Debaryomyces nepalensis AUMC 10261,10 Hanseniaspora opuntiae AUMC 10221, 11 Lachancea thermotolerans AUMC 10222, 12 Saccharomyces cerevisiae AUMC 10265,13 Saccharomyces cerevisiae AUMC 10229, 14 Saccharomyces cerevisiae AUMC 10235, 15 Saccharomycopsis fibuligera AUMC 10266, 16 Wickerhamomyces subpelliculosus AUMC 10236; Basidiomyceteous yeasts: 17 Cryptococcus magnus AUMC 10254, 18 Exobasidium sp. AUMC 10262,19 Reniforma strues AUMC 10263, 20 R. strues AUMC 10264, 21 Sterigmatomyces elviae AUMC 10267; and 22 Prototheca zopfii var. hydrocarbonea AUMC 10268.

\begin{tabular}{|c|c|c|c|c|c|c|c|c|c|c|c|c|c|c|c|c|c|c|c|c|c|c|c|}
\hline $\begin{array}{l}\text { Test /Species strain } \\
\text { number }\end{array}$ & Code & 1 & 2 & 3 & 4 & 5 & 6 & 7 & 8 & 9 & $\mathbf{1 0}$ & 11 & 12 & 13 & 14 & 15 & 16 & 17 & 18 & 19 & 20 & 21 & 22 \\
\hline $\begin{array}{l}\text { Fermentation (D- } \\
\text { glucose) }\end{array}$ & F1 & - & + & + & + & + & $\mathrm{W}$ & + & + & - & - & + & + & + & + & - & + & - & - & - & - & - & - \\
\hline \multicolumn{24}{|c|}{ Assimilation of carbon compounds } \\
\hline D-glucose & $\mathrm{C} 1$ & + & + & + & + & + & + & + & + & + & + & + & + & + & + & + & + & + & + & + & + & + & + \\
\hline D-galactose & $\mathrm{C} 2$ & + & + & - & + & + & + & + & + & + & - & + & + & + & + & - & - & + & + & - & + & + & + \\
\hline L-sorbose & C3 & + & + & - & + & + & + & + & + & + & - & + & - & - & - & - & - & + & - & - & - & + & - \\
\hline D-glucosamine & $\mathrm{C} 4$ & + & - & W & - & - & + & - & - & + & - & - & - & - & - & - & + & + & - & - & - & - & - \\
\hline D-ribose & C5 & + & - & - & + & - & - & - & + & + & - & - & - & - & - & - & + & - & + & - & - & + & - \\
\hline D-xylose & C6 & + & + & + & + & + & + & + & + & + & - & + & - & - & + & - & + & + & + & - & + & + & - \\
\hline L-arabinose & $\mathrm{C} 7$ & + & + & - & + & + & - & + & + & + & - & - & - & - & $\mathrm{W}$ & - & $\mathrm{d}$ & + & + & - & - & + & - \\
\hline L-rhamnose & C9 & - & + & - & W & - & - & $\mathrm{W}$ & - & + & - & - & - & - & - & - & - & + & $\mathrm{nt}$ & - & + & + & + \\
\hline Sucrose & $\mathrm{C} 10$ & + & + & - & + & - & + & + & + & + & - & + & + & + & + & + & + & + & + & - & + & + & + \\
\hline Maltose & C11 & + & + & + & + & $\mathrm{W}$ & + & + & + & + & + & + & + & + & + & + & + & + & + & - & + & - & + \\
\hline$\alpha, \alpha$-trehalose & C12 & + & + & - & + & - & + & + & + & + & + & + & + & + & + & + & + & + & + & - & + & + & + \\
\hline Methyl- $\alpha$-D-glucoside & C13 & + & + & - & + & - & + & + & + & + & $\mathrm{W}$ & + & + & + & + & + & + & + & + & - & + & - & $\mathrm{d}$ \\
\hline Cellobiose & C14 & + & + & - & - & + & - & + & + & + & + & + & - & - & - & + & + & + & + & - & - & + & - \\
\hline Salicin & C15 & + & + & - & - & - & - & + & + & + & + & - & + & - & - & + & + & + & + & - & $\mathrm{W}$ & + & - \\
\hline Arbutin & C16 & + & + & - & - & - & - & + & + & + & + & - & - & - & - & + & + & + & + & - & w & + & - \\
\hline Lactose & C18 & + & - & - & - & - & - & - & - & + & - & - & - & $\mathrm{W}$ & - & - & $\mathrm{nt}$ & + & - & - & $\mathrm{W}$ & + & - \\
\hline Raffinose & C19 & - & + & - & - & - & - & - & + & + & - & + & + & + & + & + & + & + & + & - & - & + & - \\
\hline Melezitose & $\mathrm{C} 20$ & + & + & - & + & - & + & + & + & + & - & + & + & + & + & + & + & + & + & - & + & - & $\mathrm{d}$ \\
\hline Inulin & $\mathrm{C} 21$ & + & + & + & + & + & + & + & + & + & + & $\mathrm{W}$ & + & - & - & + & - & + & + & + & + & + & + \\
\hline
\end{tabular}




\begin{tabular}{|c|c|c|c|c|c|c|c|c|c|c|c|c|c|c|c|c|c|c|c|c|c|c|c|}
\hline $\begin{array}{l}\text { Test /Species strain } \\
\text { number }\end{array}$ & Code & 1 & 2 & 3 & 4 & 5 & 6 & 7 & 8 & 9 & 10 & 11 & 12 & 13 & 14 & 15 & 16 & 17 & 18 & 19 & 20 & 21 & 22 \\
\hline Soluble starch & $\mathrm{C} 22$ & - & - & - & - & - & - & + & - & + & $\mathrm{W}$ & - & - & - & - & + & + & + & - & - & + & - & - \\
\hline Glycerol & $\mathrm{C} 23$ & + & + & + & + & + & + & + & + & + & - & + & + & + & + & + & + & + & + & + & + & + & + \\
\hline Meso-erythritol & $\mathrm{C} 24$ & + & W & - & - & - & - & - & - & + & - & - & - & - & - & + & + & - & + & - & - & + & - \\
\hline Ribitol & $\mathrm{C} 25$ & + & - & - & + & + & + & + & + & + & - & + & + & - & - & + & + & + & + & - & - & + & - \\
\hline Xylitol & C26 & + & + & - & + & + & + & + & + & + & - & + & - & $\mathrm{W}$ & - & - & + & + & + & - & - & + & - \\
\hline D-glucitol & $\mathrm{C} 28$ & + & + & - & + & + & + & + & + & + & - & + & $\mathrm{d}$ & $\mathrm{d}$ & - & + & + & + & + & - & $\mathrm{W}$ & + & + \\
\hline D-mannitol & C29 & +- & + & + & + & + & + & + & + & + & - & + & + & - & - & + & + & + & + & + & + & + & - \\
\hline Galactitol & $\mathrm{C} 30$ & - & - & - & - & $\mathrm{W}$ & - & - & - & + & - & - & - & - & - & - & - & + & - & - & - & - & - \\
\hline Myo-inositol & C31 & - & - & - & - & - & - & - & - & - & - & - & - & - & - & + & - & + & + & - & + & $\mathrm{W}$ & + \\
\hline Glucono-d-lactone & C32 & + & + & + & + & + & + & + & + & + & + & + & - & + & - & + & + & - & + & $\mathrm{W}$ & $\mathrm{W}$ & + & - \\
\hline 2-keto-D-gluconate & C33 & + & + & + & + & + & + & + & + & + & + & + & + & $\mathrm{W}$ & + & $\mathrm{W}$ & - & + & + & + & + & + & + \\
\hline D-gluconate & $\mathrm{C} 35$ & + & + & + & - & - & + & + & + & + & + & $\mathrm{W}$ & - & - & - & + & + & + & + & + & + & + & - \\
\hline D-glucuronate & C36 & - & - & - & - & + & - & - & + & - & - & - & - & - & - & + & - & + & + & - & - & + & + \\
\hline D-galacturonate & C37 & - & $\mathrm{W}$ & - & - & $\mathrm{nt}$ & + & - & - & + & $\mathrm{w}$ & - & - & - & - & - & - & + & + & - & - & + & - \\
\hline DL-lactate & C38 & $\mathrm{W}$ & + & + & - & + & - & - & + & + & - & $\mathrm{W}$ & + & - & - & - & + & - & + & - & + & + & + \\
\hline Succinate & C39 & + & + & + & + & + & + & + & + & + & - & + & + & - & - & + & + & + & + & - & + & + & + \\
\hline Citrate & $\mathrm{C} 40$ & + & + & + & + & + & + & + & + & + & - & - & - & $\mathrm{W}$ & - & + & + & + & - & + & $\mathrm{W}$ & + & - \\
\hline Methanol & C41 & - & - & - & - & - & - & - & - & $\mathrm{W}$ & - & - & - & - & - & - & - & - & - & - & $\mathrm{W}$ & - & + \\
\hline Ethanol & $\mathrm{C} 42$ & + & + & + & + & + & + & + & + & + & - & + & + & + & + & + & + & + & + & + & + & + & + \\
\hline Propane 1,2 diol & C43 & - & - & - & - & - & - & - & - & $\mathrm{W}$ & - & - & - & - & - & - & - & - & - & - & - & - & - \\
\hline Butane 2,3 diol & C44 & - & + & $\mathrm{W}$ & + & + & - & - & + & - & - & - & - & - & - & + & + & + & + & $\mathrm{W}$ & - & + & + \\
\hline Quinic acid & $\mathrm{C} 45$ & - & - & - & - & - & - & - & - & + & - & - & - & - & - & - & + & + & + & - & + & + & - \\
\hline \multicolumn{24}{|l|}{ Nitrogen compounds } \\
\hline Nitrate & N1 & - & + & - & - & - & - & - & + & - & - & - & - & - & - & - & + & + & $\mathrm{nt}$ & - & - & - & - \\
\hline Nitrite & $\mathrm{N} 2$ & - & + & - & - & - & - & - & + & + & - & - & - & - & - & - & + & + & $\mathrm{nt}$ & - & - & - & - \\
\hline Ethylamine & N3 & + & + & + & + & + & + & + & + & + & - & - & - & - & - & + & + & - & $\mathrm{nt}$ & + & + & + & + \\
\hline L-lysine & N4 & + & + & + & + & + & + & + & + & + & $\mathrm{W}$ & $\mathrm{W}$ & - & - & - & + & + & $\mathrm{W}$ & $\mathrm{nt}$ & + & + & + & + \\
\hline Creatine & N6 & - & - & - & $\mathrm{nt}$ & - & - & nt & - & + & - & - & - & - & - & - & - & - & $\mathrm{nt}$ & - & - & - & - \\
\hline Creatinine & N7 & - & - & - & $\mathrm{nt}$ & - & - & nt & - & + & - & - & - & - & - & - & - & - & $\mathrm{nt}$ & - & - & - & - \\
\hline D-glucosamine & N8 & + & + & $\mathrm{W}$ & + & + & + & + & + & + & - & $\mathrm{W}$ & + & $\mathrm{W}$ & $\mathrm{W}$ & + & $\mathrm{W}$ & + & $\mathrm{nt}$ & + & + & + & + \\
\hline Imidazole & N9 & - & - & - & - & - & - & - & - & - & - & - & - & - & - & - & - & - & $\mathrm{nt}$ & - & - & - & - \\
\hline D-tryptophane & N10 & + & + & + & + & + & + & + & + & + & $\mathrm{W}$ & + & - & - & - & + & - & $\mathrm{W}$ & nt & + & + & + & + \\
\hline
\end{tabular}




\begin{tabular}{|c|c|c|c|c|c|c|c|c|c|c|c|c|c|c|c|c|c|c|c|c|c|c|c|}
\hline $\begin{array}{l}\text { Test /Species strain } \\
\text { number }\end{array}$ & Code & $\mathbf{1}$ & 2 & 3 & 4 & 5 & 6 & 7 & 8 & 9 & 10 & 11 & 12 & 13 & 14 & 15 & 16 & 17 & 18 & 19 & 20 & 21 & 22 \\
\hline \multicolumn{24}{|l|}{ Miscellaneous } \\
\hline $0.01 \%$ cycloheximide & $\mathrm{O} 1$ & - & - & + & - & $\mathrm{nt}$ & - & + & - & + & + & - & - & - & - & + & + & - & - & - & - & - & - \\
\hline $0.1 \%$ cycloheximide & $\mathrm{O} 2$ & - & - & - & - & nt & - & + & - & + & + & - & - & - & - & $\mathrm{W}$ & - & - & - & - & - & - & - \\
\hline $50 \%$ D-glucose & $\mathrm{O} 4$ & + & - & - & + & + & + & + & - & + & + & + & - & + & - & - & + & - & $\mathrm{nt}$ & nt & $\mathrm{nt}$ & nt & - \\
\hline $60 \%$ D-glucose & $\mathrm{O5}$ & - & - & - & + & - & - & - & - & + & - & - & - & - & - & - & + & - & $\mathrm{nt}$ & $\mathrm{nt}$ & $\mathrm{nt}$ & $\mathrm{nt}$ & - \\
\hline $10 \% \mathrm{NaCl}$ & $\mathrm{O6}$ & + & - & - & + & + & + & - & - & + & - & - & - & - & - & - & + & - & $\mathrm{nt}$ & $\mathrm{nt}$ & $\mathrm{nt}$ & $\mathrm{nt}$ & - \\
\hline $16 \% \mathrm{NaCl}$ & $\mathrm{O} 7$ & - & - & - & - & - & - & - & - & + & - & - & - & - & - & - & - & - & $\mathrm{nt}$ & $\mathrm{nt}$ & $\mathrm{nt}$ & nt & - \\
\hline Starch formation & M1 & - & - & - & - & - & - & - & - & - & - & - & - & - & - & - & - & - & - & - & - & - & - \\
\hline
\end{tabular}

+: growth; w: weak growth; d, delayed growth, -: no growth, nt: not tested.

Table 2 Assiut University Mycological Centre accession number (AUMC) of yeast strains isolated from insect guts with accession GenBank numbers given together with the closest match in the GenBank database and sequence similarity in percent to the match as inferred from Blastn searches of ITS sequences.

\begin{tabular}{|c|c|c|c|c|c|c|}
\hline $\begin{array}{l}\text { AUMC } \\
\text { number }\end{array}$ & Isolation source & $\begin{array}{l}\text { Accession } \\
\text { GenBank } \\
\text { Number }\end{array}$ & $\begin{array}{l}\text { Length } \\
\text { (bp) }\end{array}$ & Closest Genbank match \# ITS & $\begin{array}{l}\text { Sequencing } \\
\text { similarity }(\%)\end{array}$ & Species \\
\hline 10221 & Honey bee & KX015895 & 751 & $\begin{array}{l}\text { H2S2K5=FM199954 } \\
\text { CBS 8733 }{ }^{\mathrm{T}}=\text { AJ512435 }\end{array}$ & $\begin{array}{l}742 / 745(99.60) \\
665 / 671(99.11)\end{array}$ & Hanseniaspora opuntiae \\
\hline 10222 & Honey bee & KX015896 & 683 & $\begin{array}{l}\text { CBS 6340=CU928180 } \\
\text { UniFGKT2= KT029797 } \\
\text { NRRL Y-8284 }=\text { NR_111334 }\end{array}$ & $\begin{array}{l}674 / 678(99.41) \\
637 / 637(100) \\
639 / 642(99.53)\end{array}$ & Lachancea thermotolerans \\
\hline 10223 & Honey bee & KX015898 & 682 & $\begin{array}{l}\text { CBS } 6340=C U 928180 \\
\text { NRRL Y-8284 }=\text { NR_111334 }\end{array}$ & $\begin{array}{l}676 / 678(99.71) \\
639 / 642(99.53)\end{array}$ & Lachancea thermotolerans \\
\hline 10224 & Honey bee & KX015903 & 682 & $\begin{array}{l}\text { CBS } 6340=\text { CU928180 } \\
\text { UniFGKT2= KT029797 } \\
\text { NRRL Y-8284 }=\text { NR_111334 }\end{array}$ & $\begin{array}{l}674 / 677(99.56) \\
637 / 637(100) \\
639 / 642(99.53)\end{array}$ & Lachancea thermotolerans \\
\hline 10225 & Honey bee & KX015901 & 513 & ATCC $24210^{\mathrm{T}}=\mathrm{AY} 939808$ & $501 / 508(98.62)$ & Pichia kudriavzevii \\
\hline 10226 & Honey bee & KX015902 & 514 & ATCC $24210^{\mathrm{T}}=\mathrm{AY} 939808$ & $505 / 511(98.83)$ & Pichia kudriavzevii \\
\hline 10227 & Honey bee & KX023220 & 475 & ATCC $24210^{\mathrm{T}}=\mathrm{AY} 939808$ & $425 / 470(90.43)$ & Pichia kudriavzevii \\
\hline 10228 & Honey bee & KX023221 & 471 & ATCC $24210^{\mathrm{T}}=\mathrm{AY} 939808$ & $385 / 417(92.32)$ & Pichia kudriavzevii \\
\hline
\end{tabular}




\begin{tabular}{|c|c|c|c|c|c|c|}
\hline $\begin{array}{l}\text { AUMC } \\
\text { number }\end{array}$ & Isolation source & $\begin{array}{l}\text { Accession } \\
\text { GenBank } \\
\text { Number }\end{array}$ & $\begin{array}{l}\text { Length } \\
\text { (bp) }\end{array}$ & Closest Genbank match \# ITS & $\begin{array}{l}\text { Sequencing } \\
\text { similarity }(\%)\end{array}$ & Species \\
\hline 10229 & Honey bee & KX023222 & 817 & CBS $1171^{\mathrm{T}}=\mathrm{NR} \_111007$ & $682 / 730(93.42)$ & Saccharomyces cerevisiae \\
\hline 10230 & Honey bee & KX023223 & 488 & CBS $1171^{\mathrm{T}}=\mathrm{NR} \_111007$ & $427 / 461(92.63)$ & Saccharomyces cerevisiae \\
\hline 10231 & Honey bee & KX029121 & 668 & $\begin{array}{l}\text { CBS } 432^{\mathrm{T}}=\mathrm{AJ} 229059 \\
\text { CBS } 432^{\mathrm{T}}=\mathrm{AJ} 229059 \\
\text { CBS } 1171^{\mathrm{T}}=\mathrm{NR} \_111007\end{array}$ & $\begin{array}{l}441 / 476(92.65) \\
498 / 521(95.59) \\
482 / 505(95.45)\end{array}$ & $\begin{array}{l}\text { Saccharomyces paradoxus } \\
\text { Saccharomyces paradoxus } \\
\text { Saccharomyces cerevisiae }\end{array}$ \\
\hline 10232 & Honey bee & KX029122 & 568 & $\begin{array}{l}\text { CBS } 1171^{\mathrm{T}}=\mathrm{NR} \_111007 \\
\text { CBS } 432^{\mathrm{T}}=\mathrm{AJ} 229059\end{array}$ & $\begin{array}{l}464 / 536(86.57) \\
478 / 552(86.59)\end{array}$ & $\begin{array}{l}\text { Saccharomyces cerevisiae } \\
\text { Saccharomyces paradoxus }\end{array}$ \\
\hline 10233 & Honey bee & KX029123 & 819 & $\begin{array}{l}\text { CBS } 1171^{\mathrm{T}}=\mathrm{NR} \_111007 \\
\text { CBS } 432^{\mathrm{T}}=\mathrm{AJ} 229059\end{array}$ & $\begin{array}{l}728 / 763(95.41) \\
716 / 746(95.98)\end{array}$ & $\begin{array}{l}\text { Saccharomyces cerevisiae } \\
\text { Saccharomyces paradoxus }\end{array}$ \\
\hline 10234 & Honey bee & KX029124 & 658 & $\begin{array}{l}\text { CBS } 1171^{\mathrm{T}}=\mathrm{NR} \_111007 \\
\text { ATCC MYA-4449 }=\text { NR_111355 }\end{array}$ & $\begin{array}{l}466 / 499(93.39) \\
481 / 518(92.86)\end{array}$ & $\begin{array}{l}\text { Saccharomyces cerevisiae } \\
\text { Saccharomyces kudriavzevii }\end{array}$ \\
\hline 10235 & Honey bee & KX029125 & 727 & $\begin{array}{l}\mathrm{CBS} 432^{\mathrm{T}}=\mathrm{AJ} 229059 \mathrm{CB} \overline{\mathrm{S}} \\
1171^{\mathrm{T}}=\mathrm{NR} \_111007\end{array}$ & $\begin{array}{l}546 / 626(87.22) \\
529 / 608(87.01)\end{array}$ & $\begin{array}{l}\text { Saccharomyces paradoxus } \\
\text { Saccharomyces cerevisiae }\end{array}$ \\
\hline 10236 & Honey bee & KX015897 & 637 & $\begin{array}{l}\text { PMM08-1561-AL= KP132906 } \\
\text { NRRL Y-1683 }=\text { NR_111336 }\end{array}$ & $\begin{array}{l}631 / 637(99.06) \\
578 / 580(99.66)\end{array}$ & $\begin{array}{l}\text { Wickerhamomyces } \\
\text { subpelliculosus }\end{array}$ \\
\hline 10237 & Honey bee & KX015899 & 639 & $\begin{array}{l}\text { PMM08-1561-AL= KP132906 } \\
\text { NRRL Y-1683 }=\text { NR_111336 }\end{array}$ & $\begin{array}{l}632 / 639(98.90) \\
580 / 580(100)\end{array}$ & $\begin{array}{l}\text { Wickerhamomyces } \\
\text { subpelliculosus }\end{array}$ \\
\hline 10238 & Honey bee & KX015900 & 640 & $\begin{array}{l}\text { PMM08-1561-AL = KP132906 } \\
\text { NRRL Y-1683 }=\text { NR_111336 }\end{array}$ & $\begin{array}{l}622 / 626(99.36) \\
579 / 580(99.83)\end{array}$ & $\begin{array}{l}\text { Wickerhamomyces } \\
\text { subpelliculosus }\end{array}$ \\
\hline 10239 & Honey bee & KX015904 & 637 & $\begin{array}{l}\text { PMM08-1561-AL= KP132906 } \\
\text { NRRL Y-1683 }=\text { NR_111336 }\end{array}$ & $\begin{array}{l}633 / 637(99.37) \\
579 / 580(99.83)\end{array}$ & $\begin{array}{l}\text { Wickerhamomyces } \\
\text { subpelliculosus }\end{array}$ \\
\hline 10240 & Black beetle & KX011596 & 586 & CBS $2022^{\mathrm{T}}=\mathrm{EU} 568913$ & $586 / 586(100)$ & Meyerozyma caribbica \\
\hline 10241 & Black beetle & KX011597 & 586 & CBS $2022^{\mathrm{T}}=$ EU568913 & $586 / 586(100)$ & Meyerozyma caribbica \\
\hline 10242 & Black beetle & KX011598 & 589 & CBS $2022^{\mathrm{T}}=$ EU568913 & $589 / 589(100)$ & Meyerozyma caribbica \\
\hline 10243 & Black beetle & KX011602 & 524 & $\begin{array}{l}\mathrm{ZA039}=\mathrm{FJ} 662416 \\
\mathrm{CBS} 604^{\mathrm{T}}=\mathrm{A} Y 391843\end{array}$ & $\begin{array}{l}524 / 524(100) \\
522 / 523(99.81)\end{array}$ & Candida parapsilosis \\
\hline 10244 & Black beetle & KX011603 & 520 & $\begin{array}{l}\text { UZ31_13= KM36151 } \\
\text { ATCC } 750=\text { AY939810 }\end{array}$ & $\begin{array}{l}512 / 520(98.46) \\
510 / 518(98.46)\end{array}$ & Candida tropicalis \\
\hline 10245 & Black beetle & KX015905 & 480 & $\begin{array}{l}\mathrm{LY} 2=\mathrm{KJ} 535096 \\
\text { CBS } 94^{\mathrm{T}}=\mathrm{NR} \_111250\end{array}$ & $\begin{array}{l}461 / 471(97.88) \\
452 / 468(96.58)\end{array}$ & Candida tropicalis \\
\hline
\end{tabular}




\begin{tabular}{|c|c|c|c|c|c|c|}
\hline $\begin{array}{l}\text { AUMC } \\
\text { number }\end{array}$ & Isolation source & $\begin{array}{l}\text { Accession } \\
\text { GenBank } \\
\text { Number }\end{array}$ & $\begin{array}{l}\text { Length } \\
\text { (bp) }\end{array}$ & Closest Genbank match \# ITS & $\begin{array}{l}\text { Sequencing } \\
\text { similarity }(\%)\end{array}$ & Species \\
\hline 10246 & Black beetle & KX015906 & 528 & $\begin{array}{l}\text { CNRMA10.725=KP131996 } \\
\text { CBS } 1600^{\mathrm{T}}=\mathrm{NR} \_111211\end{array}$ & $\begin{array}{l}405 / 520(77.89) \\
389 / 499(77.96)\end{array}$ & Cyberlindnera jadinii \\
\hline 10247 & Red palm weevil & KX011604 & 617 & $\begin{array}{l}\text { WM } 03.488=K P 131656 \text { CBS } \\
1913^{\mathrm{T}}=\mathrm{NR} \_077069\end{array}$ & $\begin{array}{l}606 / 607(99.84) \\
579 / 580(99.83)\end{array}$ & Candida aaseri \\
\hline 10248 & Red palm weevil & KX011600 & 417 & PMM10-923-L= KP131807 & 415/416(99.75) & Candida pararugosa \\
\hline 10249 & Red palm weevil & KX011605 & 605 & $\begin{array}{l}\text { 10H1064=KF220648 } \\
\text { CBS } 4412^{\mathrm{T}}=\mathrm{AM} 158924\end{array}$ & $\begin{array}{l}601 / 604(99.50) \\
597 / 605(98.68)\end{array}$ & Candida quercitrusa \\
\hline 10250 & Red palm weevil & KX015890 & 618 & $\begin{array}{l}\text { 10H1064=KF220648 } \\
\text { CBS } 4412^{\mathrm{T}}=\mathrm{AM} 158924\end{array}$ & $\begin{array}{l}613 / 616(99.51) \\
609 / 619(98.38)\end{array}$ & Candida quercitrusa \\
\hline 10251 & Red palm weevil & KX015889 & 521 & $\begin{array}{l}\text { ZA038= FJ662410 } \\
\text { ATCC } 750=A Y 939810\end{array}$ & $\begin{array}{l}520 / 521(99.81) \\
515 / 516(99.81)\end{array}$ & Candida tropicalis \\
\hline 10252 & Red palm weevil & KX015907 & 488 & $\begin{array}{l}\text { ZA038= FJ662410 } \\
\text { ATCC } 750=A Y 939810 \\
\text { CBS } 94^{\mathrm{T}}=\mathrm{NR} \_111250\end{array}$ & $\begin{array}{l}452 / 492(91.87) \\
445 / 482(92.32) \\
439 / 476(92.22)\end{array}$ & Candida tropicalis \\
\hline 10253 & Red palm weevil & KX015908 & 493 & $\begin{array}{l}\text { ATCC } 750=A Y 939810 \\
\text { CBS } 94^{\mathrm{T}}=\mathrm{NR} \_111250\end{array}$ & $\begin{array}{l}475 / 485(97.94) \\
471 / 480(98.13)\end{array}$ & Candida tropicalis \\
\hline 10254 & Red palm weevil & KX015893 & 654 & $\begin{array}{l}\text { AUMC 7246=JQ425371 } \\
\text { CBS } 140^{\mathrm{T}}=\mathrm{NR} \_130655 \\
\text { CBS } 8361=\mathrm{AF} 444388\end{array}$ & $\begin{array}{l}653 / 655(99.69) \\
557 / 558(99.82) \\
557 / 558(99.82)\end{array}$ & Cryptococcus magnus \\
\hline 10255 & Red palm weevil & KX011601 & 572 & $\begin{array}{l}\text { CNRMA } 10.725=\mathrm{KP} 131996 \\
\text { CBS } 621=\mathrm{EU} 568909 \\
\text { CBS } 1600^{\mathrm{T}}=\mathrm{NR} \_111211\end{array}$ & $\begin{array}{l}551 / 565(97.52) \\
545 / 564(96.63) \\
510 / 522(97.70)\end{array}$ & Cyberlindnera jadinii \\
\hline 10256 & Red palm weevil & KX015892 & 572 & $\begin{array}{l}\text { CNRMA } 10.725=\mathrm{KP} 131996 \\
\text { CBS } 621=\text { EU568909 } \\
\text { CBS } 1600^{\mathrm{T}}=\mathrm{NR} \_111211\end{array}$ & $\begin{array}{l}544 / 560(97.14) \\
535 / 560(95.54) \\
506 / 524(96.56)\end{array}$ & Cyberlindnera jadinii \\
\hline 10257 & Red palm weevil & KX015909 & 521 & $\begin{array}{l}\text { CNRMA } 10.725=\mathrm{KP} 131996 \\
\text { CBS } 1600^{\mathrm{T}}=\mathrm{NR} \_111211 \\
\text { CBS } 621=\text { EU568909 }\end{array}$ & $\begin{array}{l}455 / 513(88.69) \\
449 / 503(89.26) \\
452 / 513(88.11)\end{array}$ & Cyberlindnera jadinii \\
\hline 10258 & Red palm weevil & KX015910 & 351 & CBS $1600^{\mathrm{T}}=\mathrm{NR} \_111211$ & $261 / 328(79.57)$ & Cyberlindnera jadinii \\
\hline 10259 & Red palm weevil & KX015911 & 536 & $\begin{array}{l}\text { CBS } 621=\text { EU568909 } \\
\text { CBS } 1600^{\mathrm{T}}=\mathrm{NR} \_111211\end{array}$ & $\begin{array}{l}415 / 526(78.90) \\
403 / 510(79.02)\end{array}$ & Cyberlindnera jadinii \\
\hline
\end{tabular}




\begin{tabular}{|c|c|c|c|c|c|c|}
\hline $\begin{array}{l}\text { AUMC } \\
\text { number }\end{array}$ & Isolation source & $\begin{array}{c}\text { Accession } \\
\text { GenBank } \\
\text { Number }\end{array}$ & $\begin{array}{l}\text { Length } \\
\text { (bp) }\end{array}$ & Closest Genbank match \# ITS & $\begin{array}{l}\text { Sequencing } \\
\text { similarity }(\%)\end{array}$ & Species \\
\hline 10260 & Red palm weevil & KX029126 & 392 & $\begin{array}{l}\text { CNRMA10.725=KP131996 } \\
\text { CBS 621=EU568909 }\end{array}$ & $\begin{array}{l}322 / 390(82.56) \\
298 / 363(82.09)\end{array}$ & Cyberlindnera jadinii \\
\hline 10261 & Red palm weevil & KX011606 & 645 & 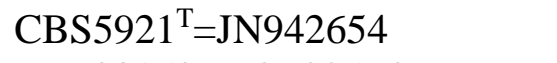 & $639 / 643(99.64)$ & Debaryomyces nepalensis \\
\hline 10262 & Red palm weevil & KX011608 & 573 & $\begin{array}{l}\text { IBL } 03150=\text { DQ682574 } \\
\text { PC1=KM403454 }\end{array}$ & $\begin{array}{l}571 / 572(99.83) \\
569 / 574(99.13)\end{array}$ & $\begin{array}{l}\text { Exobasidiomycetidae sp. } \\
\text { Exobasidiales sp. }\end{array}$ \\
\hline 10263 & Red palm weevil & KX011609 & 583 & CBS $8263^{\mathrm{T}}=$ NR_073314 & $518 / 594(87.21)$ & Reniforma strues \\
\hline 10264 & Red palm weevil & KX015891 & 592 & CBS $8263^{\mathrm{T}}=\mathrm{NR} \_073314$ & $525 / 601(87.35)$ & Reniforma strues \\
\hline 10265 & Red palm weevil & KX011599 & 776 & $\begin{array}{l}\text { CBS2888= KY109257 } \\
\text { CBS } 1171^{\mathrm{T}}=\mathrm{NR} \_111007\end{array}$ & $\begin{array}{l}770 / / 770(100) \\
749 / 753(99.47)\end{array}$ & Saccharomyces cerevisiae \\
\hline 10266 & Red palm weevil & KX015894 & 636 & $\begin{array}{l}\text { AUMC 9092 }=\text { KU052788 } \\
\text { CBS 329.83 }=\text { AF218988 }\end{array}$ & $\begin{array}{l}635 / 635(100) \\
370 / 370(100)\end{array}$ & Saccharomycopsis fibuligera \\
\hline 10267 & Red palm weevil & KX011607 & 642 & CBS 5922 ${ }^{\mathrm{T}}=\mathrm{NR} \_073301$ & 638/638(100) & Sterigmatomyces elviae \\
\hline 10268 & Red palm weevil & KX015912 & 751 & UP-PT-P63=HG515044 & $636 / 639(99.53)$ & $\begin{array}{l}\text { Prototheca zopfii var. } \\
\text { hydrocarbonea }\end{array}$ \\
\hline
\end{tabular}


Table 3 Comparison between the frequencies of occurrence of fungal species recovered from guts of the three different insects (honey bees, black beetles and red-palm weevil insects).

\begin{tabular}{|c|c|c|c|c|c|c|}
\hline \multirow[t]{2}{*}{ Fungi } & \multicolumn{2}{|c|}{ Honey bees } & \multicolumn{2}{|c|}{$\begin{array}{l}\text { Black } \\
\text { beetles }\end{array}$} & \multicolumn{2}{|c|}{$\begin{array}{l}\text { Red-palm } \\
\text { weevils }\end{array}$} \\
\hline & $\mathrm{N}=\mathbf{2 8}$ & $\%$ & $\mathrm{~N}=11$ & $\%$ & $\mathbf{N}=11$ & $\%$ \\
\hline Filamentous fungi & 21 & 75 & 11 & 100 & 9 & 81.81 \\
\hline Aspergillus & 18 & 67.85 & 10 & 90.90 & 4 & 36.36 \\
\hline A.brasiliensis Varga, Frisvad \& Samson & 1 & 3.57 & & & & \\
\hline A. flavus Link & 7 & 25 & & & & \\
\hline A. flavus var. columnaris Raper \& Fennell & & & 1 & 9.09 & & \\
\hline A. fumigatus Fresenius & & & 1 & 9.09 & & \\
\hline A. lacticofeatus Samson \& Frisvad & & & & & 1 & 9.09 \\
\hline A. montevidensis Talice \& J.A. Mackinnon & 1 & 3.57 & & & & \\
\hline A. nidulans (Eidam) G. Winter & 2 & 7.14 & & & & \\
\hline A. niger van Tieghem & 12 & 42.86 & 8 & 72.72 & 2 & 18.18 \\
\hline A. ochraceus Wilhelm & 1 & 3.57 & & & 1 & 9.09 \\
\hline A.parasiticus Speare & 1 & 3.57 & 2 & 18.18 & 1 & 9.09 \\
\hline A. proliferans G. Smith & 1 & 3.57 & 1 & 9.09 & & \\
\hline A. recurvatus Raper \& Fennell & 1 & 3.57 & & & & \\
\hline A. sydowii (Bainier \& Sartory) Thom \& Church & 2 & 7.14 & & & & \\
\hline A. taichungensis Yaguchi, Someya \& Udagawa & & & 2 & 18.18 & 1 & 9.09 \\
\hline A. terreus Thom & 5 & 17.85 & 3 & 27.27 & 2 & 18.18 \\
\hline A. versicolor (Vuillemin) Tiraboschi & & & 1 & 9.09 & & \\
\hline Chaetomium sp. & 5 & 17.85 & 1 & 9.09 & & \\
\hline Cladosporium & 6 & 21.43 & 6 & 54.55 & 5 & 45.45 \\
\hline $\begin{array}{l}\text { C.chlorocephalum (Fresen.) E.W.Mason \& } \\
\text { M.B. Ellis }\end{array}$ & 1 & 3.57 & & & 1 & 9.09 \\
\hline C. cladosporioides (Fresen.) G.A. de Vries & 2 & 7.14 & 2 & 18.18 & 5 & 45.45 \\
\hline C. herbarum (Pers.) Link & 2 & 3.57 & & & & \\
\hline C. oxysporum Berkeley \& Curtis & 1 & 3.57 & 1 & 9.09 & & \\
\hline C. sphaerospermum Penzig & & & 3 & 27.27 & 1 & 9.09 \\
\hline Bipolaris clavata Alcorn & 1 & 3.57 & & & & \\
\hline Cochliobolus & 2 & 7.14 & & & & \\
\hline C. australiensis (Tsuda \& Ueyama) Alcorn & 1 & 3.57 & & & & \\
\hline C. lunatus R. Nelson \& Haasis & 1 & 3.57 & & & & \\
\hline C. pallescens (Tsuda \& Ueyama) Sivanesan & 1 & 3.57 & & & & \\
\hline Cunninghamella echinulata (Thaxter) Thaxter & & & & & 1 & 9.09 \\
\hline Fusarium & 2 & 7.14 & & & 5 & 45.45 \\
\hline F. proliferatum (Matsushima) Nirenberg & 1 & 3.57 & & & & \\
\hline F. solani (Martius) Saccardo & & & & & 4 & 36.36 \\
\hline F. verticillioides (Saccardo) Nirenberg & 1 & 3.57 & & & 1 & 9.09 \\
\hline $\begin{array}{l}\text { Gondwanamyces serotectus van der Linde \& } \\
\text { Jol. Roux }\end{array}$ & & & & & 2 & 18.18 \\
\hline Mucor & 2 & 7.14 & & & 1 & 9.09 \\
\hline M. circinelloides van Tieghem & & & & & 1 & 9.09 \\
\hline M. hiemalis Wehmer & 2 & 7.14 & & & & \\
\hline Myceliophthora thermophila (Apinis) Oorschot & 1 & 3.57 & & & & \\
\hline Nigrospora oryzae (Berkeley \& Broome) Petch & 1 & 3.57 & & & & \\
\hline Penicillium & 6 & 21.43 & 5 & 45.45 & 2 & 18.18 \\
\hline P. chrysogenum Thom & 4 & 14.28 & 5 & 45.45 & 2 & 18.18 \\
\hline P.crustosum Thom & & & & & 1 & 9.09 \\
\hline P. griseofulvum Dierckx & & & & & 1 & 9.09 \\
\hline
\end{tabular}




\begin{tabular}{|c|c|c|c|c|c|c|}
\hline \multirow[t]{2}{*}{ Fungi } & \multicolumn{2}{|c|}{ Honey bees } & \multicolumn{2}{|c|}{$\begin{array}{l}\text { Black } \\
\text { beetles }\end{array}$} & \multicolumn{2}{|c|}{$\begin{array}{l}\text { Red-palm } \\
\text { weevils }\end{array}$} \\
\hline & $\mathrm{N}=\mathbf{2 8}$ & $\%$ & $\mathrm{~N}=11$ & $\%$ & $\mathrm{~N}=11$ & $\%$ \\
\hline P. oxalicum Currie \& Thom & 2 & 7.14 & & & & \\
\hline P. puberulum Bainier & & & 1 & 9.09 & 1 & 9,09 \\
\hline P. purpurogenum Stoll & & & 2 & 18.18 & & \\
\hline Papulospora immersa Hotson & 1 & 3.57 & & & & \\
\hline $\begin{array}{l}\text { Pochonia suchlasporia var. catenata (W. Gams } \\
\text { \& Dackman) Zare \& W. Gams }\end{array}$ & 1 & 3.57 & & & & \\
\hline $\begin{array}{l}\text { Pseudallescheria boydii (Shear) McGinnis et } \\
\text { al. }\end{array}$ & & & & & 1 & 9.09 \\
\hline Scopulariopsis & 3 & 10.71 & 2 & 18.18 & 1 & 9.09 \\
\hline S. brevicaulis (Sacc.) Bainier & 3 & 10.71 & & & & \\
\hline S. chartarum (G. Smith) Morton \& J. Smith & & & 2 & 18.18 & & \\
\hline S. japonicum Udajawa et al. & & & & & 1 & 9.09 \\
\hline Stachybotrys chartarum (Ehrenberg) Hughes & 1 & 3.57 & & & & \\
\hline Stemphylium sarciniforme (Cavara) Wiltshire & & & & & 1 & 9.09 \\
\hline Steril mycelia (dark) & & & 1 & 9.09 & & \\
\hline $\begin{array}{l}\text { Triadelphia sp. near to } T \text {. disseminata Madrid } \\
\& \text { J. Edathodu }\end{array}$ & & & & & 1 & 9.09 \\
\hline Trichothecium roseum (Persoon: Fries) Link & 1 & 3.57 & & & & \\
\hline Yeasts & 16 & 57.14 & 4 & 36.36 & 11 & 100 \\
\hline Candida & & & 1 & 9.09 & 7 & 63.63 \\
\hline $\begin{array}{l}\text { C. aaseri Dietrichson ex van Uden \& H.R. } \\
\text { Buckley }\end{array}$ & & & & & 2 & 18.18 \\
\hline C. parapsilosis (Ashford) Langeron \& Talice & & & 1 & 9.09 & 1 & 9.09 \\
\hline C. pararugosa Nakase, Komagata \& Fukazawa & & & & & 2 & 18.18 \\
\hline C. quercitrusa S.A. Meyer \& Phaff & & & & & 2 & 18.18 \\
\hline C. tropicalis Berkhout & & & 1 & 9.09 & 4 & 36.36 \\
\hline $\begin{array}{l}\text { Cryptococccus magnus (Lodder \& Kreger) } \\
\text { Baptist \& Kurtzman }\end{array}$ & & & & & 1 & 9.09 \\
\hline $\begin{array}{l}\text { Cyberlindnera jadinii (Sartory, R. Sartory, } \\
\text { Weill \& J. Mey.) Minter }\end{array}$ & & & 1 & 9.09 & 11 & 100 \\
\hline Debaryomyces nepalensis Goto \& Sugiyama & & & & & 1 & 9.09 \\
\hline Exobasidium sp. & & & 1 & 9.09 & 1 & 9.09 \\
\hline $\begin{array}{l}\text { Hanseniaspora opuntiae Cadez, Poot, Raspor } \\
\text { \& M.T. Sm. }\end{array}$ & 1 & 3.57 & & & & \\
\hline $\begin{array}{l}\text { Lachancea thermotolerans (Filippov) } \\
\text { Kurtzman }\end{array}$ & 10 & 35.71 & & & & \\
\hline $\begin{array}{l}\text { Meyerozyma caribbica (Vaughan-Mart., } \\
\text { Kurtzman, S.A. Mey. \& E.B. O'Neill) } \\
\text { Kurtzman \& M. Suzuki }\end{array}$ & & & 2 & 18.18 & 2 & 18.18 \\
\hline Pichia kudriavzevii Boidin, Pignal \& Besson & 7 & 25 & & & & \\
\hline $\begin{array}{l}\text { Reniforma sp. near to } R \text {. strues Pore \& } \\
\text { Sorenson }\end{array}$ & & & & & 2 & 18.18 \\
\hline Saccharomyces & 7 & 25 & & & 5 & 45.45 \\
\hline S. cerevisiae Meyen ex E.C. Hansen (>95\%) & 2 & 7.14 & & & 5 & 45.45 \\
\hline Saccharomyce sp. near to $S$. cerevisiae $(<95 \%)$ & 7 & 25 & & & & \\
\hline $\begin{array}{l}\text { Saccharomycopsis fibuligera (Lindner) } \\
\text { Klöcker }\end{array}$ & & & & & 1 & 9.09 \\
\hline Sterigamtomyces elviae Sonck \& Yarrow & & & & & 1 & 9.09 \\
\hline
\end{tabular}




\begin{tabular}{|c|c|c|c|c|c|c|}
\hline \multirow[t]{2}{*}{ Fungi } & \multicolumn{2}{|c|}{ Honey bees } & \multicolumn{2}{|c|}{$\begin{array}{l}\text { Black } \\
\text { beetles }\end{array}$} & \multicolumn{2}{|c|}{$\begin{array}{l}\text { Red-palm } \\
\text { weevils }\end{array}$} \\
\hline & $\mathrm{N}=\mathbf{2 8}$ & $\%$ & $\mathbf{N}=11$ & $\%$ & $\mathrm{~N}=\mathbf{1 1}$ & $\%$ \\
\hline Wickerhamomyces subpelliculosus (Kurtzman) & 4 & 14.28 & & & & \\
\hline Kurtzman, Robnett \& Basehoar-Powers & & & & & & \\
\hline $\begin{array}{l}\text { Prototheca zopfii var. hydrocarbonea } \\
\text { (Kockova'-Kratochvilova \& Havelkova) Pore }\end{array}$ & & & & & 9 & 81.81 \\
\hline Number of genera (36) & 23 & & 9 & & 21 & \\
\hline Number of species (68+3 varieties) & $38+1$ & & $20+1$ & & $35+1$ & \\
\hline
\end{tabular}

$\mathrm{N}=$ number of insects from which yeast or filamentous fungal species were recovered.

Calderon O, Berkov A. 2012 - Midgut and fat body bacteriocytes in neotropical cerambycid beetles (Coleoptera: Cerambycidae). Environmental Entomology 41, 108-117.

Callaham RZ, Shifrine M. 1960 - The yeasts associated with bark beetles. Forest Science 6, 146154.

Chahbar N, Mohamed AL. 2014 - Contribution to identification of the microflora of the digestive tract and pollen of Allgerian honeybees: Apis mellifera intermissa and Apis mellifera sahariensis. International Journal of Current Microbiology and Applied Science 3, 601-607.

Cox ML. 1993 - Red palm weevil Rhynchophorus ferrugineus in Egypt. FAO Plant Protection Bulletin 41, 30-31.

Dembilio Ó, Jacas JA. 2011 - Basic bio-ecological parameters of the invasive Red Palm Weevil, Rhynchophorus ferrugineus (Coleoptera: Curculionidae), in Phoenix canariensis under Mediterranean climate. Bulletin of Entomological Research 101, 153-163.

Domsch KH, Gams W, Anderson T-H. 2007 - Compendium of soil fungi, $2^{\text {nd }}$ ed., IHW-Verlag, Eching.

El-Sebaey Y. 2004 - Field evaluation of certain insecticides against red palm weevil Rhynchophorus ferrugineus Oliv. (Coleoptera, Curculionidae) in Egypt. Egyptian Journal of Agriculural Research $82,1591-1599$.

Faleiro JR. 2006 - A review on the issues and management of red palm weevil Rhynchophorus ferrugineus (Coleoptera: Rhynchophoridae) in coconut and date palm during the last one hundred years. International Journal of Tropical Insect Science 26, 135-154.

Ferry M, Gomez S. 2002 - The Red Palm Weevil in the Mediterranean area. Palms 46, 172-178.

Ganter PF. 2006 - Yeast and invertebrate associations. In: Rosa CA, Peter G (eds), Biodiversity and Ecophysiology of Yeasts, The Yeast Handbook. Heidelberg, Springer, pp 303-370.

Gilliam M. 1973 - Are yeasts present in adult worker honey bees as a consequence of stress? Annals of the Entomological Society of America 66(5), 1176.

Gilliam M. 1997 - Identification and roles of non-pathogenic microflora associated with honey bees. FEMS Microbiology Letters 155, 1-10.

Gilliam M, Prest DP. 1972 - Fungi isolated from the intestinal contents of foraging worker honey bees, Apis mellifera. Journal of Invertebrate Pathology 20, 101-103.

Gilliam M, Prest BP, Morton HL. 1974a - Fungi isolated from honey bees, Apis mellifera, fed 2,4D and antibiotics. Journal of Invertebrate Pathology 24, 349-356.

Gilliam M, Wickerham LJ, Morton HL, Martin RD. 1974b - Yeasts isolated from honey bees, Apis mellifera, fed 2,4-D and antibiotics. Journal of Invertebrate Pathology 24, 213-217.

Gilliam M, Morton HL, Prest DP, Martin RD, Wickerham LJ. 1977 - The mycoflora of adult worker honeybees, Apis mellifera: effects of 2,4,5-T and caging of bee colonies. Journal of Invertebrate Pathology 30, 50-54.

Gilliam JW, Skaggs RW, Weed SB. 1979 - Drainage control to diminish nitrate loss from agricultural fields. Journal of Environmental Quality 8, 137-142.

Gilliam M, Taber IIIS, Lorenz BJ, Prest DB. 1988a - Factors affecting development of chalkbrood disease in colonies of honey bees, Apis mellifera, fed pollen contaminated with Ascosphaera apis. Journal of Invertebrate Pathology 52, 314-325. 
Gilliam M, Lorenz BJ, Richardson GV. 1988b - Digestive enzymes and microorganisms in honey bees, Apis mellifera influence of streptomycin, age, season and pollen. Microbios 55, 95-114.

Glinski Z, Jarosz J. 1995 - Mechanical and biochemical defenses of honey bees. Bee World 76, 110 118.

Grunwald S, Pilhofer M, Holl W. 2010 - Microbial associations in gut systems of wood- and barkinhabiting longhorned beetles [Coleoptera: Cerambycidae]. Systematic and Applied Microbiology 33, 25-34.

Houseknecht JL, Hart EL, Suh S-O, Zhou JJ. 2011 - Yeasts in the Sugiyamaella clade associated with wood-ingesting beetles and the proposal of Candida bullrunensis sp. nov. International Journal of Systematic and Evolutionary Microbiology 61, 1751-1756.

Hui F-L, Niu Q-H, Ke T, Liu Z. 2012 - Candida ficus sp. nov., a novel species from the gut of Apriona germari larvae. International Journal of Systematic and Evolutionary Microbiology 62, 2805-2809.

Hui F-L, Chen L, Chu X-Y, Niu Q-H, Ke T. 2013 - Wickerhamomyces mori sp. nov., an anamorphic yeast species found in the guts of wood-boring insect larvae. International Journal of Systematic and Evolutionary Microbiology 63, 1174-1178.

Kurtzman CP. 2001 - Six new anamorphic ascomycetous yeasts near Candida tanzawaensis. FEMS Yeast Research 1, 177-185.

Kurtzman CP, Robnett CJ. 1998 - Three new insect-associated species of the yeast genus Candida. Canadian Journal of Microbiology 44, 965-973.

Lachance MA, Bowles JM, Kwon S, Marinoni G et al. 2001a - Metschnikowia lochheadii and Metschnikowia drosophilae, two new yeast species isolated from insects associated with flowers. Canadian Journal of Microbiology 47, 103-109.

Lachance MA, Starmer WT, Rosa CA, Bowles JM et al. 2001b - Biogeography of the yeasts of ephemeral flowers and their insects. FEMS Yeast Research 1, 1-8.

Lachance MA, Ewing CP, Bowles JM, Starmer WT. 2005 - Metschnikowia hamakuensis sp. nov, Metschnikowia kamakouana sp. nov., and Metschnikowia mauinuiana sp. nov., three endemic yeasts from Hawaiian nitidulid beetles. International Journal of Systematic and Evolutionary Microbiology 55, 1369-1377.

Leslie JF, Summerell BA. 2006 - The Fusarium Laboratory manual. Blackwell Publishing: Iowa, USA.

Marti GA, Garcia JJ, Cazau MC, Lopez Lastra CC. 2007 - Fungal flora of the digestive tract of Triatoma infestans (Hemiptera: Reduviidae) from Argentina. Boletín de la Sociedad Argentina de Botánica 42, 175-179.

Moraes De AML, Junqueira ACV, Costa GL, Celano V et al. 2000 - Fungal flora of the digestive tract of 5 species of triatomines vectors of Trypanosoma cruzi, Chagas, 1909. Mycopathologia $151,41-48$.

Moraes DE AML, Junqueira ACV, Celano V, Da Costa GL, Coura JR. 2004 - Fungal flora of the digestive tract of Rhodnius prolixus, Rhodnius neglectus, Diptelanogaster maximus and Panstrongylus megistus, vectors of Trypanosoma cruzi, Chagas, 1909. Brazilian Journal of Microbiology 35, 288-291.

Mousavi F, Beheshti-Maal K, Massah A. 2015 - Production of sophorolipid from an identified current yeast, Lachancea thermotolerans BBMCZ7FA20, isolated from honey bee. Current Microbiology 71, 303-310.

Moubasher AH. 1993 - Soil fungi in Qatar and other Arab countries. The Scientific and Applied Research Center, University of Qatar, Doha, pp. 566.

Nardon P, Grenier AM. 1989 - Endosymbiosis in Coleoptera: biological, biochemical, and genetic aspects. In: Schwemmler W, Gassner G (eds), Insect erndocytobiosis: morphology, physiology, genetics, evolution. CRC Press, Boca Raton, FL, pp. 175-216.

Nguyen NH, Suh S-O, Erbil CK, Blackwell M. 2006 - Metschnikowia noctiluminum sp. nov., Metschnikowia corniflorae sp. nov., and Candida chrysomelidarum sp. nov., isolated from green lacewings and beetles. Mycological Research 110, 346-356. 
Nguyen NH, Suh S-O, Blackwell M. 2007 - Five novel Candida species in insect-associated yeast clades isolated from Neuroptera and other insects. Mycologia 99, 842-858.

Perez J, Munoz-dorado J, De La Rubia T, Martinez J. 2002 - Biodegradation and biological treatments of cellulose, hemicellulose and lignin: an overview. International Microbiology 5, 5363.

Pimentel MR, Antonini Y, Martins RP, Lachance MA, Rosa CA. 2005 - Candida riodocensis and Candida cellae, two new yeast species from the Starmerella clade associated with solitary bees in the Atlantic rain forest of Brazil. FEMS Yeast Research 5, 875-879.

Pitt JI. 1979 - The genus Penicillium and its teleomorphic states Eupenicillium and Talaromyces. Academic Press, London, pp. 635.

Raper KB, Fennell DI. 1965 - The genus Aspergillus. Williams \& Wilkins Co., Baltimore.

Rios-velasquez, C, Hamada N. 2002 - Trichmycete fungi (Zygomycota) associated with the digestive tract of Simulium goelldii Cequeira \& Nunes de Mello and Simulium ulyssesi (Py-Daniel \& Coscaron) (Diptera: Simuliidae) larvae, in central Amazonia, Brazil. Mem Inst Oswaldo Cruz 97, 423-426.

Rivera FN, Gonzalez E, Gomez Z. 2009 - Gut-associated yeast in bark beetles of the genus Dendroctonus Erichson (Coleoptera: Curculionidae: Scolytinae). Biological Journal of the Linnean Society 98, 325-342.

Rojas-Jimenez K, Hernandez M. 2015 - Isolation of fungi and bacteria associated with the guts of tropical wood-feeding Coleoptera and determination of their lignocellulolytic activities. International Journal of Microbiology, vol. 2015, Article ID 285018, 11 pages, 2015.

Rosa CA, Lachance MA, Silva JOC, Teixeira ACP et al. 2003 - Yeast communities associated with stingless bees. FEMS Yeast Research 4, 271-275.

Sandhu DK, Waraich MK. 1985 - Yeasts associated with pollinating bees and flower nectar. Microbial Ecology 11, 51-58.

Sivanesan A. 1987 - Graminicolus species of Bipolars, Curvularia, Drecshlera, Exserohilum and their teleomorphs. International Mycological Institute, Kew, Surrey, England.

Starmer WT, Lachance MA. 2011 - Yeast Ecology, In: Kurtzman CP, Fell JW, Boekhout T (eds.) The Yeasts: A Taxonomic Study, $5^{\text {th }}$ edn, Elsevier: Amsterdam, pp. 65-86.

Suh, S-O, Blackwell M. 2004 - Three new beetle-associated yeasts in the Pichia guilliermondii clade. FEMS Yeast Research 5, 87-95.

Suh S-O, Blackwell M. 2005 - The beetle gut as a habitat for new species of yeasts. In: Vega FE, Blackwell M (eds) Insect Fungal Associations: ecology and evolution. Oxford University Press, New York, pp. 244-256.

Suh S-O, Blackwell M. 2006 - Three new asexual arthroconidial yeasts, Geotrichum carabidarum sp. nov., Geotrichum histeridarum sp. nov., and Geotrichum cucujoidarum sp. nov., isolated from the gut of insects. Mycoloical Research 110, 220-228.

Suh S-O, Marshall CJ, Mchugh JV, Blackwell M. 2003 - Wood ingestion by passalid beetles in the presence of xylose-fermenting gut yeasts. Molecular Ecology 12, 3137-3145.

Suh S-O, Gibson CM, Blackwell M. 2004a - Metschnikowia chrysoperlae sp. nov., Candida picachoensis sp. nov. and Candida pimensis sp. nov., isolated from the green lacewings Chrysoperla comanche and Chrysoperla carnea (Neuroptera: Chrysopidae). International Journal of Systematic and Evolutionary Microbiology 54, 1883-1890.

Suh S-O, Mchugh JV, Blackwell M. 2004b - Expansion of the Candida tanzawaensis yeast clade: 16 novel Candida species from basidiocarp-feeding beetles. International Journal of Systematic and Evolutionary Microbiology 54, 2409-2429.

Suh S-O, Mchugh JV, Pollock DD, Blackwell M. 2005a - The beetle gut: a hyperdiverse source of novel yeasts. Mycological Research 109, 261-265.

Suh S-O, Nguyen NH, Blackwell M. 2005b - Nine new Candida species near C. membranifaciens isolated from insects. Mycological Research 109, 1045-1056. 
Suh S-O, Nguyen NH, Blackwell M. 2006 - A yeast clade near Candida kruesii uncovered: nine novel Candida species associated with basidioma-feeding beetles. Mycological Research 110, 1379-1394.

Suh S-O, Nguyen NH, Blackwell M. 2008a - Yeasts isolated from plant-associated beetles and other insects: seven novel Candida species near Candida albicans. FEMS Yeast Research 8, 88-102.

Suh S-O, Zhang N, Nguyen N, Gross S, Blackwell M. 2008b - Lab Manual for yeast study. Mycology Lab., Louisiana State University, pp. 3-38.

Teixeira ACP, Marini MM, Nicoli JR, Antonini Y et al. 2003 - Starmerella meliponinorum sp. nov., a novel ascomycetous yeast species associated with stingless bees. International Journal of Systematic and Evolutionary Microbiology 53, 339-343.

Thompson JD, Higgins DG, Gibson TJ. 1994 - CLUSTAL W: improving the sensitivity of progressive multiple sequence alignment through sequence weighting, position-specific gap penalties and weight matrix choice. Nucleic Acids Research 22, 4673-4680.

Urbina H, Schuster J, Blackwell M. 2013 - The gut of Guatemalan passalid beetles: a habitat colonized by cellobiose- and xylose-fermenting yeast. Fungal Ecology 6, 339-355.

Urubschurov V, Janczyk P. 2011 - Biodiversity of yeasts in the gastrointestinal ecosystem with emphasis on its importance for the host. In O. Grillo and G. Venora (ed.). Environmental Sciences: the Dynamical processes of biodiversity - Case studies of evolution and spatial distribution. InTech, pp. 277-302.

Vale LG, White MM, Cafero MJ. 2008 - Harpellales in the digestive tracts of Ephemeroptera and Plecoptera nymphs from Veracruz, Mexico. Mycologia 100, 149-162.

Vega FE, Dowd PF. 2005 - The role of yeasts as insect endosymbionts, in: Vega, F.E., Blackwell, M. (Eds), Insect-fungal associations: ecology and evolution. Oxford University Press, New York, pp. 211-243.

Wang J, Xu S, Strongman DB. 2010 - Two new Harpellales inhabiting the digestive tracts of midge larvae and other trichomycetes from Tianshan Mountains, China. Mycologia 102, 155-141.

Wickerham LJ. 1951 - Taxonomy of yeasts. Technical Bulletin 1029, U.S. Deparment of Agriculture, Washington D.C.

Zare R, Gams W. 2004 - A monograph of Verticillium section Prostrata. Rostaniha (Botanical Journal of Iran) 3, 1-180. 